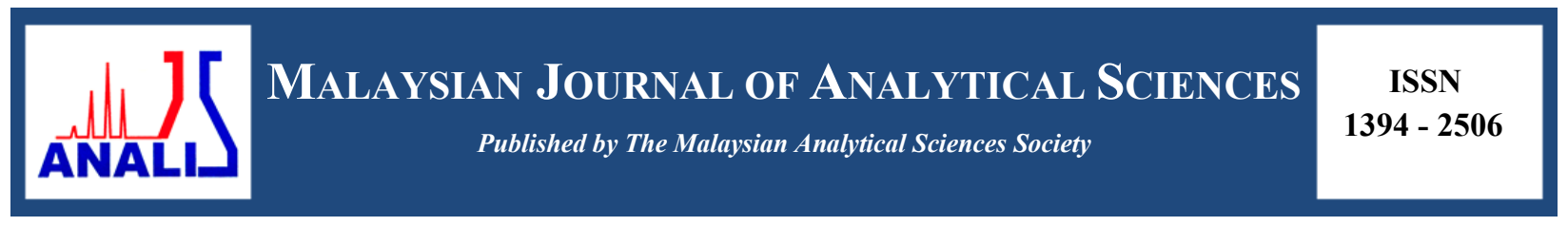

\title{
SPECIES AND SEROTYPE-SPECIFIC DETERMINATION OF ENDOTOXINS USING LC-MS
}

\author{
(Penentuan Spesies dan Serotip-Khusus Endotoksin Menggunakan LC-MS) \\ Anna Karen Carrasco Laserna ${ }^{1}$, Huatao Feng $^{1}$, Sam Fong Yau Li ${ }^{1,2 *}$ \\ ${ }^{1}$ Department of Chemistry, Faculty of Science, \\ National University of Singapore, 3 Science Drive 3, Singapore 11754, Singapore \\ ${ }^{2}$ NUS Environmental Research Institute, \\ \#02-01 T-Lab Building, 5A Engineering Drive 1, Singapore 117411, Singapore \\ *Corresponding author: chmlifys@nus.edu.sg
}

Received: 7 November 2016; Accepted: 18 September 2017

\begin{abstract}
Endotoxins or lipopolysaccharides (LPS) are characteristic components of the outer cellular membrane of Gram negative bacteria, which are recognition targets of immune receptors and are responsible for inciting the bacteria's toxic effects. The toxicity and physiological effects of LPS varies diversely within and across different bacterial species. However, the current standard test for endotoxin analysis, the Limulus Amoebocyte Lysate (LAL) test, can only provide information on the presence of LPS, regardless of which bacteria the LPS is coming from. As implied from the name "lipopolysaccharide", LPS has a lipid and a carbohydrate portion. The carbohydrate component is further subdivided to the core oligosaccharide and the O-antigen polysaccharide chains, which are conserved within species and unique for each serotype, respectively. In this pilot study, we fingerprinted the oligosaccharide units generated from mild acid hydrolysis of the LPS from some serotypes of Escherichia coli and Salmonella, as well as from Serratia marcesens using liquid chromatography coupled to a high resolution mass spectrometer (LC-MS) after labelling them to improve MS ionization. Multivariate analysis showed distinct clustering of samples belonging to each bacterial species and revealed certain features that can be potential species and serotype-specific markers of LPS from the different bacteria under study.
\end{abstract}

Keywords: endotoxins, lipopolysaccharide, oligosaccharide fingerprinting, liquid chromatography - mass spectrometry

\begin{abstract}
Abstrak
Endotoksin atau lipopolisakarida (LPS) adalah komponen teras membran selular luaran bakteria Gram negatif yang bertindak untuk mengenalpasti sasaran reseptor imun dan bertanggungjawab menguatkan kesan toksik bakteria tersebut. Terdapat perbezaan dalam ketoksikan dan kesan fisiologi LPS di dalam dan antara spesies bakteria yang berbeza. Walau bagaimanapun, ujian piawai semasa bagi analisis endotoksin, ujian Limulus Amebosit Lisat (LAL), hanya boleh memberikan maklumat mengenai kehadiran LPS tanpa mengira bakteria sumber asal LPS tersebut. Nama lipopolisakarida juga menunjukkan bahawa LPS mempunyai lipid dan sebahagian unsur karbohidrat. Komponen karbohidrat juga terbahagi kepada oligosakarida teras dan rantai polisakarida O-antigen, yang terpelihara di dalam spesies dan unik untuk setiap serotip yang hadir. Dalam kajian rintis ini, kami mengenalpasti unit oligosakarida yang dihasilkan daripada hidrolisis asid lemah LPS dari beberapa serotip dari Escherichia coli, Salmonella dan juga Serratia marcescens menggunakan kromatografi cecair digunakan bersama spektrometri jisim resolusi tinggi (LC-MS) selepas proses pelabelan untuk meningkatkan pengionan MS. Analisis multivariat menunjukkan kelompok tertentu sampel yang datang dari setiap spesies bakteria dan mendedahkan ciri - ciri tertentu yang boleh menjadi spesies yang berpotensi dan penanda serotip spesifik LPS dari bakteria yang berbeza di bawah kajian.
\end{abstract}

Kata kunci: endotoksin, lipopolisakarida, oligosakarida cap jari, kromatografi cecair - spektrometri jisim 


\section{Introduction}

Endotoxins or lipopolysaccharides (LPS) are characteristic components of the outer cellular membrane of Gram negative bacteria. In the event of a bacterial infection, they are the recognition targets of the innate immune system and they are responsible for the toxicological effect of the bacteria [1]. When immune cells recognize their presence upon binding, the inflammatory response of the body will be triggered to resolve the infection. However, if the infection is overwhelming, complications may arise such as the development of endotoxic shock [2]. This can lead to multiple organ failure and can be fatal.

LPS is mainly composed of a lipid and a carbohydrate part, thus the name "lipopolysaccharide". Generally, its structure is divided into three main parts: the lipid A, the core oligosaccharide, and the O-polysaccharide or Oantigen chain. The lipid A is made up of ester or amide-linked fatty acid chains of varying lengths that is conserved for each bacterial species and is known to be the active part responsible for the bacteria's toxicity. Changes in its structure can affect the activity of the endotoxin. The core oligosaccharide is further subdivided into an inner and outer core. The inner core mainly consists of unusual sugars such as 3-deoxy-D-manno-octulosonic acid (Kdo) and L-glycero-D-manno-heptose. The outer core consists of more common sugars such as hexoses and hexosamines. The core oligosaccharide is mostly conserved within bacterial species. Lastly, there is the O-polysaccharide or Oantigen chain. It consists of repeating subunits of carbohydrate chains with varying lengths having high specificity for each serotype of the same species. It is the part that binds with immune receptors and induces the antigenic effect, thus the name O-antigen [1,3]. It can be seen that there is great diversity in the structure of the LPS among different bacterial species and even within the same species. This diversity also results in different innate immune response, different degrees of toxicity, and trigger of different physiological responses to individuals [4].

The current gold standard for LPS analysis is the Limulus amoebocyte lysate (LAL) test. The test is based on the agglutination of the amoebocyte lysate obtained from horseshoe crab in the presence of endotoxins. Other methods of endotoxin analysis include rabbit pyrogenic testing, cell and antibody binding assays, molecular binding biosensors, and recombinant bacteriophage binding [5]. For tests like LAL and rabbit pyrogenic testing, there is a concern on sustainability due to their use of animals. Most of these tests are highly sensitive and quantitative. However, they are also mostly non-specific methods of endotoxin detection. They only determine and measure the amount of endotoxin present but do not provide information as to what bacterial species or serotype the endotoxin comes from. On the other hand, there are also assays and biosensors that are highly specific to certain serotypes, thus requiring multiple assays in order to detect the presence of different species and serotypes. Given that different LPS can induce different antigenic and toxicological effects, there is a need for species and serotype-specific determination of LPS.

Chemical fingerprinting has been used in different fields of application for purposes of quality control, authentication, and origin identification [6]. It is based on the understanding that different organisms, species, and even those of the same species raised in different conditions will have their own unique molecular profiles. It can be done using different compounds ranging from DNA to small molecule metabolites and using different analytical platforms. Mass spectrometry (MS)-based analysis are commonly used in fingerprinting as they provide high sensitivity and compound identity information based on mass and fragmentation data. MS analysis is usually coupled with separation techniques such as gas chromatography (GC), liquid chromatography (LC) or capillary electrophoresis (CE) in order to further improve specificity by resolving isomers and increase sensitivity by reducing the number of analytes detected at any given time that may otherwise suppress or interfere with each other. Given that the carbohydrate component of bacterial LPS provides both species and serotype information, we explore the feasibility of fingerprinting different LPS based on their oligosaccharide features.

\section{Chemicals}

\section{Materials and Methods}

The LPS standards of Salmonella enterica serotype abortus equi, Salmonella enterica serotype minnesota, Salmonella typhosa, Serratia marcesens, Escherichia coli O55:B5, and Escherichia coli K-235 were all purchased from Sigma-Aldrich (St. Louis, MO, USA). The reagents 7-(diethylamino) coumarin-3-carbohydrazide (CHH), as well as LC-MS grade formic acid, acetic acid, ammonium formate, and acetonitrile (ACN), were also purchased 
from Sigma-Aldrich. Ultrapure water $(18.2 \Omega)$ was obtained from an UltraClear TWF water purification system by EvoQua (Fahrenberg, Germany).

\section{Sample preparation}

Each sample of LPS standard was weighed $(0.20 \pm 0.05 \mathrm{mg})$ into a centrifuge vial and subjected to mild acid hydrolysis in order to remove the lipid A component. Mild acid hydrolysis was performed by adding $100 \mu \mathrm{l}$ of $1 \%$ acetic acid to the sample followed by heating for 1 hour at $90{ }^{\circ} \mathrm{C}$. The samples were then centrifuged, the supernatant was taken and freeze dried. The samples were kept in $-80{ }^{\circ} \mathrm{C}$ until labelling and analysis. The samples were then labelled based on a modification of the method reported by Milic et al. for CHH labelling [7]. Briefly, a volume of $100 \mu \mathrm{l}$ of $2 \mathrm{mg} / \mathrm{ml} \mathrm{CHH}$ in $50 \% \mathrm{ACN}$ was added to the dried LPS hydrolysate. The samples were then incubated in the dark for 3 hours in a temperature controlled shaker at $37^{\circ} \mathrm{C}$. All LPS standards were prepared and analyzed in triplicates.

\section{LC-MS analysis}

The LC-MS analysis was performed using a Dionex Ultimate 3000 RSLC system (Thermo Fisher Scientific, USA) coupled to an AB Sciex Triple TOF 5600 MS (Sciex, USA). Chromatographic separation was done using a Glycan BEH Amide column (Waters, USA) with dimensions of $2.1 \times 100 \mathrm{~mm}$ and particle size of 1.8 micron. The mobile phase solvents used were $50 \mathrm{mM}$ ammonium formate $(\mathrm{pH} \mathrm{4.5)}$ in water (A) and acetonitrile (B), with an initial flow rate of $0.4 \mathrm{ml} / \mathrm{min}$. The gradient program employed for the separation was as follows: $85 \% \mathrm{~B}$ to $50 \% \mathrm{~B}$ for the first 25 minutes, 50 to $30 \% \mathrm{~B}$ from 25 to 27 minutes with a reduction in flow rate to $0.2 \mathrm{ml} / \mathrm{min}, 0 \% \mathrm{~B}$ at 28 minutes to 30 minutes with flow rate increased to $0.4 \mathrm{ml} / \mathrm{min}$ at the end of this step, 0 to $85 \% \mathrm{~B}$ from 30 to 31.5 minutes, and lastly, equilibration for 6.6 minutes. Data acquisition was done in positive electrospray ionization mode. The mass range scanned was from 100 to 2500 Dalton $(\mathrm{Da})$ with an accumulation time of 0.2 second. The nebulizer and heater gases were set at 45 and $50 \mathrm{psi}$, respectively, the curtain gas was at $30 \mathrm{psi}$, heater temperature at $450{ }^{\circ} \mathrm{C}$, and the ion spray voltage was set to 5,000 volts (V). The declustering potential (DP) was set at $80 \mathrm{~V}$ and collision energy (CE) was at $10 \mathrm{~V}$. MS/MS data was obtained using information dependent acquisition (IDA) wherein the 10 highest intensity ions per cycle were subjected to product ion scan at collision energy (CE) of $35 \mathrm{~V}$ with CE spread of $15 \mathrm{~V}$. Automated mass calibration was done every three hours using the AB Sciex APCI positive calibration solution (Sciex, USA).

\section{Data processing and analysis}

The MS data acquisition files were converted to mzXML format using MSConvert (Proteowizard). The files were then uploaded to XCMS online for retention time alignment, peak picking and annotation. The resulting data matrix was exported to Excel for further processing. Peaks common with the reagent blank were removed from the dataset as well as identified isotopic signals. Median normalization was performed to ensure comparability of all samples by reducing the effects of variations from sample weighing and changes in the sensitivity of the instrument through time. All values were $\log 2$ transformed to reduce the effects of variations in high intensity variables and prevent them from masking the contributions of lower intensity variables. Multivariate analysis was performed using SIMCA P+ 12 (MKS Umetrics, Sweden). Principal Components Analysis (PCA) was performed to identify inherent clustering of samples or presence of trends and identify possible outliers. Supervised analysis was also performed using Orthogonal Projection to Latent Structures- Discriminant Analysis (OPLS-DA). Features that are either species or serotype-specific were identified by looking at the contributions plot of the OPLS-DA model.

\section{Results and Discussion}

In this pilot study, we looked at the oligosaccharide fingerprints of two serotypes of Escherichia coli (EC O55:B5 and EC K-235), two serotypes of Salmonella enterica (minnesota and abortus equi, SEM and SEA), Salmonella typhosa (ST), and Serratia marcesens (SM). Most carbohydrates do not have functional groups that can be easily used for their detection and they are also not easily ionisable for MS detection. They can be analyzed in negative ionization mode under highly basic conditions but with lower sensitivity. Thus, they are usually derivatized or labelled with moieties that will aid in their detection [8]. Fluorescent reagents like 8-aminopyrene-1,3,6-trisulfonic acid (APTS) and MS ionisable reagents like 2-aminobenzoic acid (2-AB), 2-anthranilic acid (2-AA), and more recently, RapiFluor MS [9], are used to label sugars for detection. However, such reagents require reductive amination in order to react the reducing sugar moiety with the label. It requires the use of a highly toxic reagent, 
sodium cyanoborohydride, and an SPE clean-up step. There are also labelling reagents that can react directly with the reducing sugar moiety via hydrazone formation, such as 2-(4-phenethylphenyl)acetohydrazide [10], which allows simpler sample preparation for MS analysis. For this project, we tried the use of a common fluorescent reagent, 7-(diethylamino)coumarin-3-carbohydrazide $(\mathrm{CHH})$ for the labelling of the oligosaccharides via hydrazone formation and subsequent MS detection. It has been previously reported for use in MS analysis of carbonylated lipids [7] given that it can react readily with aldehydes and ketones via the hydrazide moiety and have good ionization in MS with the tertiary amine moiety. We hypothesize that we can also use it to easily tag the reducing sugar moiety of the oligosaccharides and be used for MS analysis of the oligosaccharides. Furthermore, it can also be used for fluorescence detection.

Figure 1 shows the total ion chromatogram (TIC) of the different LPS samples analyzed. It can be seen that each LPS has its own distinct profile. In the chromatographic dimension, there are peaks that appear at the same retention time across different species and serotypes. The use of MS adds another dimension of resolution by differentiating the components eluting at the same retention time based on mass. While this offers better specificity, it also produces a complex data matrix with high dimensionality. Multivariate statistical analysis, commonly used to analyze such data matrices and reveal useful information [11], was used in this study to analyze the complex data matrix.

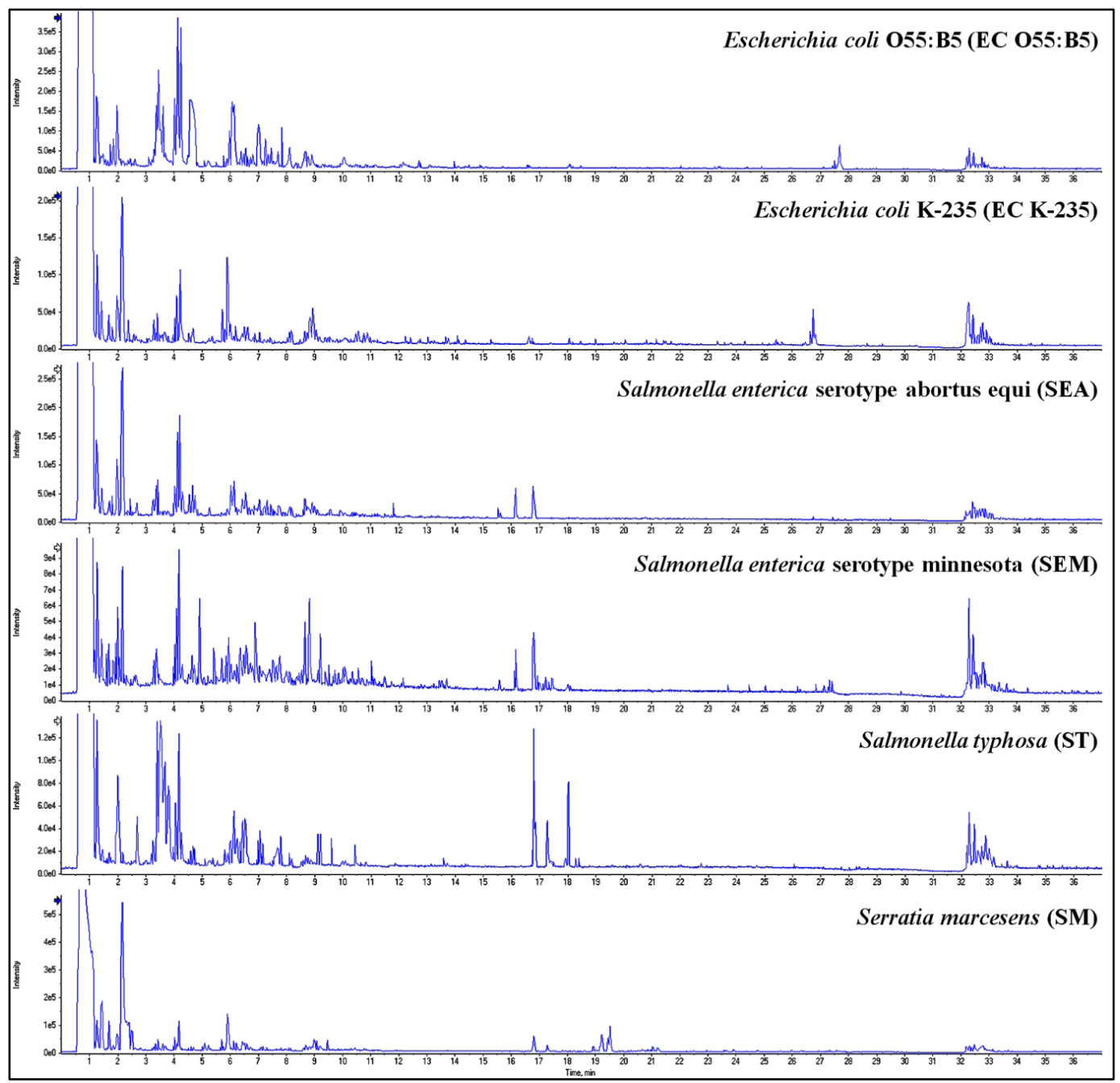

Figure 1. TIC of the different LPS samples labelled with $\mathrm{CHH}$ 
PCA was used to reduce the high dimensionality of the data to a few components that can account for the variance across the samples. This allows for visualization of inherent groupings and trends in the data. The PCA model generated has a cumulative $R^{2} X$ value of 0.833 and cumulative $Q^{2}$ of 0.499 . The cumulative $R^{2} X$ represents the fraction of variation from all the variables $(\mathrm{X})$ that can be explained by the components of the model. The cumulative $\mathrm{Q}^{2}$ is the fraction of the variation that can be predicted by the model through cross-validation using a "leave-one-out" approach [12]. Both serve as measures of the quality of the model. A good model should have $\mathrm{R}^{2} \mathrm{X}$ close to 1 with the $\mathrm{Q}^{2}$ approaching or close to the $\mathrm{R}^{2} \mathrm{X}$ value. The model has a good cumulative $\mathrm{R}^{2} \mathrm{X}$ but low $\mathrm{Q}^{2}$. This can be an indication of the presence of unwanted variance from the variables affecting the model. OPLS-DA, a supervised multivariate analysis technique, can be used to take out the variance that is not related to the class information by putting them into orthogonal component/s and maximize the separation between sample groups (classes). The OPLS-DA model of the dataset has a cumulative $\mathrm{R}^{2} \mathrm{X}$ of $0.838, \mathrm{R}^{2} \mathrm{Y}$ of 0.99 and a $\mathrm{Q}^{2}$ of $0.928 . \mathrm{R}^{2} \mathrm{Y}$ represents the fraction of variation related to the class information $(\mathrm{Y})$ that can be explained by the components of the model. $\mathrm{Q}^{2}$ in this case, represents variation of $\mathrm{Y}$ that can be predicted by the components of the model and it should be as close as possible to the $R^{2} Y$ [12]. High values of $R^{2} X, R^{2} Y$, and $Q^{2}$ show that a good model has been obtained. Cross validation was also done using CV-ANOVA resulting in a $\mathrm{p}$ value of $2.35 \times 10^{-12}$ (p value $<<<0.05$ ) showing the high reliability and significance of the model.

Figure 2 shows the score plots of the samples using PCA and OPLS-DA. There is good clustering of the samples for each LPS standard in both plots, indicating good reproducibility of the fingerprints. It can also be observed that the E. coli serotypes, EC O55:B5 and EC K-235 are mainly in the lower quadrant, whereas the Salmonella species and serotypes, ST, SEA, and SEM, are in the upper quadrant. Serratia marcescens (SM) samples are in the middle, between the upper and lower quadrants. It can also be seen that SEM and SEA cluster closer together away from ST, confirming the ability to distinguish species within the same genera using the oligosaccharide features.
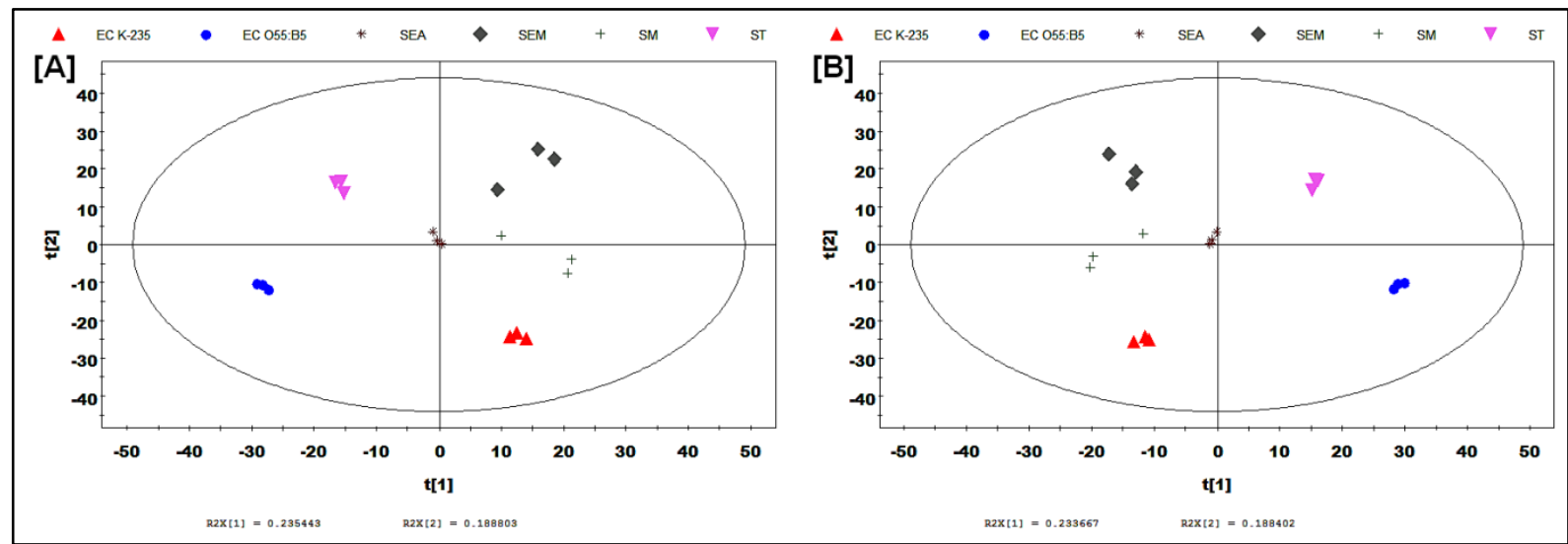

Figure 2. (a) PCA score plot showing the distinct clustering of the LPS samples from different bacterial species and serotypes, and (b) OPLS-DA score plot of the samples

Identification of variables distinct to each serotype and species were identified by looking at contribution plots of the OPLS-DA model. Contribution plots are used to visualize how an observation or group is different from others in model. It displays the differences in scaled units of the observation or group compared to the average of the rest for all variables of the model. Variables with score contribution greater than two were identified as potential species or serotype-specific oligosaccharide feature. This is confirmed by looking at the variable plot for the identified variables. Represented in Figure 3 is an example of a contribution plot showing the variables differentiating SM from the other LPS. The differentiating features are those variables whose scores are above the contribution score cut-off (orange line). The MS and MS/MS information obtained from these species and serotype- differentiating features can be used to develop targeted multiple reaction monitoring (MRM) analysis that will allow the simultaneous determination of LPS coming from different bacterial species and serotypes. 


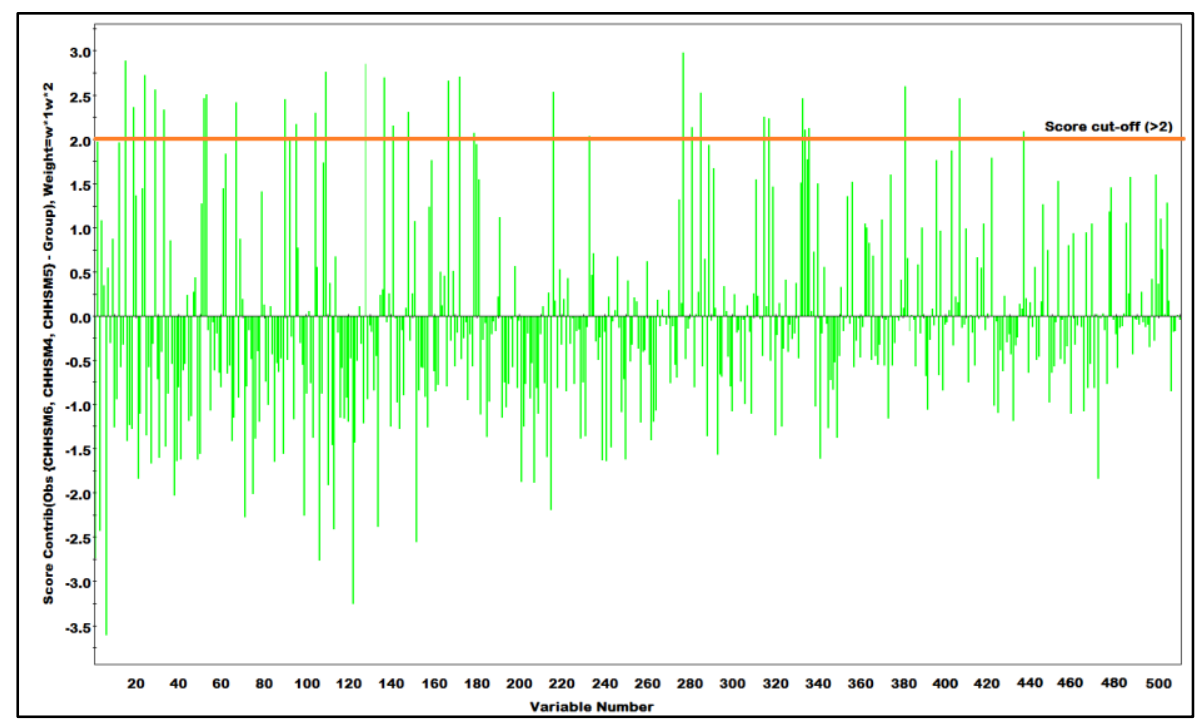

Figure 3. Contribution plot for Serratia marcesens (SM)

During the identification of species and serotype-specific features, it was noted that the MS/MS spectra of some of these oligosaccharide features do not have the reporter ions of CHH-labelled compounds (m/z 276 and 244, Figure 4a) [7]. Instead, their MS/MS spectra showed the presence of characteristic HexNAc ions (m/z 204 and 168, Figure 4b) [13], indicating that these oligosaccharide features are unlabelled oliogosaccharides having $\mathrm{N}$-acetylamine moieties. While it is good that such distinct oligosaccharide features can be identified and differentiated based on their characteristic fragmentation pattern, this still highlights the need for further investigation and optimization of the labelling conditions.
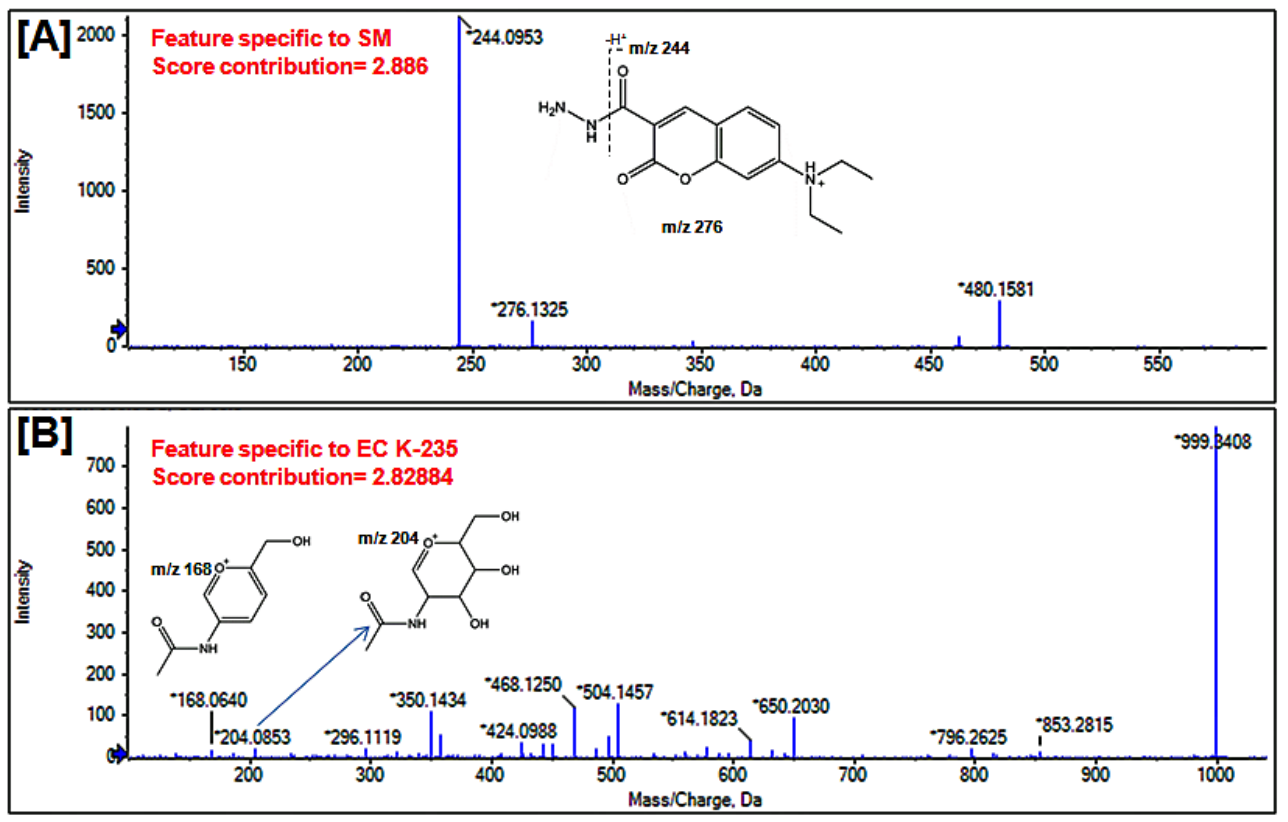

Figure 4. Sample MS/MS spectra of identified distinct oligosaccharide features 


\section{Conclusion}

The results of the study demonstrated the feasibility of using oligosaccharide fingerprinting for the species and serotype-specific determination of LPS. Good reproducibility of fingerprints has been obtained across the different bacterial species and serotypes, as shown by the good clustering of samples in the multivariate analysis models. Presence of unlabelled oligosaccharides was found from MS/MS data warranting further improvements in the labelling method. Identified species and serotype-specific oligosaccharide features from the fingerprinting can be used for the development of a targeted method for the simultaneous determination of LPS from different bacteria. It is hoped that this can eventually be used for different applications such as in environmental water and air monitoring, as well as in clinical settings.

\section{Acknowledgement}

The research grant for this study (1301-IRIS-026) is supported by the Singapore National Research Foundation under its Environment \& Water Research Programme and administered by PUB, Singapore's National Water Agency. We also acknowledge funding support from NUS and Thermo Fisher through the NUS-Thermo Fisher Strategic Alliance. The authors would also like to thank Ms. Nur Wahdiah Binte Mohamed Safit for the help with the Malay translations.

\section{References}

1. Erridge C., Bennett-Guerrero E. and Poxton I. R. (2002). Structure and function of lipopolysaccharides. Microbes and Infection, 4 (8): 837 - 851.

2. Abbott, J. D., Ball, G., Boumpas, D., Bridges, S. L., Chatham, W. and Curtis, J. (2004). Endotoxic shock in rheumatology and immunology therapy. Springer Berlin Heidelberg. pp. $302-303$.

3. Holst O. (2011). Structure of the lipopolysaccharide core region, in bacterial lipopolysaccharides: structure, chemical synthesis, biogenesis and interaction with host cells, Y.A. Knirel, M.A. Valvano, Editors. Springer Vienna. pp. $21-39$.

4. Miller S. I., Ernst R. K. and Bader M. W. (2005). LPS, TLR4 and infectious disease diversity. Nature Review Microbiology, 3(1): $36-46$.

5. Das A. P., Kumar P. S. and Swain S. (2014). Recent advances in biosensor based endotoxin detection. Biosensors Bioelectron, 51: 62 - 75.

6. Ellis D. I., Brewster V. L., Dunn W. B., Allwood J. W., Golovanov A. P. and Goodacre R. (2012). Fingerprinting food: Current technologies for the detection of food adulteration and contamination. Chemical Society Reviews, 41(17): 5706 - 5727.

7. Milic I., Hoffmann R. and Fedorova M. (2013). Simultaneous detection of low and high molecular weight carbonylated compounds derived from lipid peroxidation by electrospray ionization-tandem mass spectrometry. Analitical Chemistry, 85 (1): 156 - 162.

8. Ruhaak L.R., Zauner G., Huhn C., Bruggink C., Deelder A. M. and Wuhrer M. (2010). Glycan labeling strategies and their use in identification and quantification. Analytical and Bioanalytical Chemistry, 397(8): $3457-3481$.

9. Lauber M. A., Yu Y-Q., Brousmiche D. W., Hua Z., Koza S. M., Magnelli P., Guthrie, E., Taron, C. H. and Fountain, K. J. (2015). Rapid preparation of released N-glycans for HILIC analysis using a labeling reagent that facilitates sensitive fluorescence and ESI-MS detection. Analytical Chemistry, 87(10): 5401 - 5409.

10. Walker S. H., Lilley L. M., Enamorado M. F., Comins D. L. and Muddiman D.C. (2011). Hydrophobic derivatization of $\mathrm{N}$-linked glycans for increased ion abundance in electrospray ionization mass spectrometry. Journal of American Society Mass Spectrometry, 22(8): 1309 - 1317.

11. Eriksson L., Antti H., Gottfries J., Holmes E., Johansson E., Lindgren F., Long, I., Lundstedt, T., Trygg, J. and Wold, S. (2004). Using chemometrics for navigating in the large data sets of genomics, proteomics, and metabonomics (gpm). Analytical and Bioanalytical Chemistry, 380(3): $419-429$.

12. Umetrics (2008). User guide to SIMCA-P+ Version 12. M.K.S. Umetrics, Malmo, Sweden.

13. Zhao P., Viner R., Teo C. F., Boons G-J., Horn D. and Wells L. (2011). Combining high-energy C-trap dissociation and electron transfer dissociation for protein O-GlcNAc modification site assignment. Journal of Proteome Research, 10(9): 4088 - 4104. 